\title{
Human Rights Violations: An Impetus for Police Reforms in Kenya Between 1978 and 2002
}

\author{
Nelson Mugweru Njiri* \\ Department of International Relations, Conflict and Strategic Studies, Kenyatta University \\ Dr. Susan Mwangi \\ Department of History and Archaeological Studies, Kenyatta University \\ Dr. Joseph Wasonga \\ Department of International Relations, Conflict and Strategic Studies, Kenyatta University
}

\begin{abstract}
Since independence, police reforms have been influenced by the need to expand democratic space and to ensure protection of human rights. Previous studies have attempted to deconstruct the police reforms. However, the studies have not adequately examined the implications of police reforms on human rights in Kenya. This paper examines police reforms between in Kenya between 1978 and 2002 and their implications on human rights. The study was based on a descriptive survey design and targeted senior serving and retired police officers, government administrators, county government administrators and members of the human rights groups in Nairobi County. Purposive sampling technique was used to select 116 study participants. Data was collected through focus group discussion, interview schedule and document analysis and analyzed based on thematic content analysis. The study findings revealed that Moi's presidency (between 1978 and 2002) was marked by minimal police reforms but heightened human rights violation including arrests without warrants, detention without trial and torture which resulted in injury and death. This implied that in the absence of substantive reforms, the police disregarded human rights. Hence, the period between 1978 and 2002 was marked by curtailed freedom of association, assembly, speech and expression.
\end{abstract}

Keywords: Human Rights, Police Reforms, human rights discourse, Moi era, Kenya

DOI: $10.7176 / \mathrm{JLPG} / 103-06$

Publication date: November $30^{\text {th }} 2020$

\subsection{Introduction}

Police reforms refer to a plethora of activities related to the transformations in the police institutions (Waller, 2012; Waller, 2012). While being under enormous pressure to counter the increasing wave of crime and threats to security, including those emanating from terrorism, the police has been required to operate in accordance with stipulated laws (Ajulu, 2002). Around the world, the history of police is replete with the use of excessive force and torture (Savage, 2007). For example, in the United Kingdom, police service has been unable to adapt to the evolving social context and to embrace reform in a culture too resistant to change. In the United States of America, crime rate increased in the 1960s widening the gap between community and the police. This sparked strong criticisms regarding police relations with ethnic minority groups and marginalized populations (Skogan, 1993).

In African countries, the quest for reforming the police force was driven by inefficiencies in the police service and suppression of human freedoms (Waller, 2012). In South Africa, the key elements of police reforms revolved around access to police services in post-apartheid era (Bruce, 2003). In Kenya, police reform initiatives were influenced by the low level of trust between the police and the public (Hahn, 2003). Gimode (2007) notes that the transformative police reform has been elusive partly because the police has been implicated in human rights violations.

In the period between 1978 and 2002 during Moi's presidency, human rights violations were rampant and the complex intersection of contextual, operational, bureaucratic and cultural constraints complicated human rights-compliant policing. As a result, police reforms were needed to safeguard the rights of the incarcerated and the fundamental freedoms and rights of the citizens. However, the efforts to regulate police did not minimize violation of human rights. Instead, the police remained coercive and unfriendly and implicated in torture, neglect, arbitrary arrests and extra-judicial killings (Gimode, 2007). This raised concerns as to whether the police reforms had any positive impact on human rights. This formed the basis of the study which examined the factors that informed police reforms in Kenya between 1978 and 2002 and their implications on human rights in Kenya.

\subsection{Literature Review}

When Kenyatta died in 1978, Moi was regarded as the most suitable leader to steer the country towards a more inclusive and tolerant county. This was confirmed in December 1978 when Moi released political prisoners 
across ethnic divide. This was followed by a declaration of non-tolerance to tribalism, corruption and misuse of power by state security agencies (Haugerud, 1995). Many Kenyans interpreted these actions as evidence of the beginning of a new era in which tenets of democracy, rule of law and protection of human rights would be adhered to (Moi, 1986). In due course, however, Moi changed and begun to centralize power while taming those people he considered enemies to his leadership. As a result the issues of human rights protection turned out to be a distant concern (Haugerud, 1995).

The Change the Constitution Movement was launched to protest against Moi's excesses (Moi, 1986). However, Moi's close associates opposed the movement making it to fizzle out. Eventually, Moi succeeded to systematically entrench authoritarian and oppressive one-man state rule characterized by dictatorship and human rights violations (Haugerud, 1995). For instance, Moi criminalized competitive politics and deployed the security forces to suppress any forms of dissidence. In addition, the president usurped the functions of other state organs to the extent that the principle of separation of powers became fuzzy. Consequently, patronage remained characteristic of Moi's leadership and embarrassingly enjoyed praise from civil servants and KANU officials (Hannan, 1991). All this implies that the autocratic patronage system established by Moi undermined the rule of law and respect for human rights in Kenya. It was an authoritarian system in which the president delegated no responsibilities and became personally involved in the management of the country. This denied the citizens the rights to enjoy freedom of speech and assembly.

Through presidential directive, several constitutional amendments were made including the Amendment Act, Number 7 of 1982, which introduced Section 2(A) which transformed the country into a de jure one-party state. The president also ordered the parliament to reinstate detention laws which had been suspended in 1978 . Consequently, the colonial era laws like the Chief's Authority Act, the Preservation of Public Security Act and the Public Order Act were reintroduced to give the president the right to undermine citizens' rights to selfdetermination (Maina, 1996). As a result even members of parliament and their representatives surrendered their constitutional rights to the presidency thus insubordinating the supremacy of the legislature to the presidency and the ruling party (Maina, 1996). In this regard, it was the provincial administration that became the focal points of influence with the provincial administrators empowered to clear party meetings while isolating dissenters. These reorganizations and restructurings had a number of implications with respect to human rights. For instance, the provincial administration now had the power to prevent elected dissident members of parliament from addressing their own constituents. Others were denied the right to defend their electoral seats while tribal welfare associations were banned. These included the Luo Union, the Gikuyu, Embu, and Meru Association (GEMA), the Abaluhya Union as well as the Civil Servants Union (CSU) and the Nairobi University Academic Staff Union (UASU).

More widespread violation of human rights was witnessed during the military coup attempt in 1982 by junior Kenya Air Force officers. This was followed by further judicial amendments (Act No. 14-1986 and Act No.4-1988) which resulted into far reaching human rights violations. These amendments provided for the removal of the security and tenure of the Attorney General, the Controller and Auditor General, the judges of the High Court and the Court of Appeal. The control of parliament and the judiciary meant that the office of the president was in a position to manipulate the functions of the two arms of the government thus usurping the autonomy of both the parliament and the judiciary (Maina, 1996).

President Moi's control of parliament was extended to elections which were conducted through queuing instead of secret ballot. In this system candidates who secured more than 70 percent of the votes were declared winners (Garland, 1996). The infamous queuing system encouraged electoral malpractices such declaring results before the end of polling time and announcing the pro-government losing candidate as the winner. These practices denied the electorate their right to elect their preferred candidates thus undermining the citizens' right to self-determination (Garland, 1996).

In examining Moi's authoritarian regime, it is clear that the period was marked by massive detentions, torture, arbitrary arrests and police brutality. The idea of human rights was generally considered alien during this period. It is this understanding that led to the arrest and detention of many sitting MPs, university lecturers and student leaders who were accused of agitating for multiparty politics (Mutua, 1993). For instance, the emergence of Mwakenya in 1989 set the stage for more widespread human rights violations in which many academic elites were arrested and detained for their alleged association with Mwakenya. Consequently, between 1989 and 1991 severe instances of human rights violations were witnessed in Kenya while minimal reform initiatives were initiated. Mwakenya gave Moi a new impetus to savagely subvert multiparty activities (Mutua, 1993). Arrests and detentions in inhuman conditions followed every one of Moi's warnings against his critics. At Moi's command, the police often moved quickly to arrest those in the forefront in advocating for democracy (Widner, 1994). Suppression of freedom was extended to the press, civil societies and literary criticism. For instance, in 1991 Moi banned the production of George Orwell's Animal Farm and Ngugi Wa Thiongo's play Ngaahika Ndeenda as they were considered treasonous in their attacks on post-independence dictators (Ross, 1992).

The church remained the central locus of dissent against Moi regime (Sabar-Friedman, 1997). The Anglican 
Church emphasized the church's moral obligation to protest when rights and civil liberties were violated and to give voice to the voiceless. But using the church as a refuge did not deter the regime from arresting, assaulting and detaining its critics even within the church compounds. A case in point is the arrest of Rev. Timothy Njoya in 1988 for suggesting that Kenyans should hold discussions on critical questions affecting the country (SabarFriedman, 1997). Continued agitation by clergymen, lawyers and other human rights and pro-democracy advocates to end human rights violations was persistently resisted and this intensified during the Saba Saba movement in 1990. Upon resumption of multi-party era, continuous human rights violations by the police continued unabated (Widner, 1994). The arbitrary arrests, detentions, and judicial interference also continued for most of the 1990s (Auerbach, 2003). During political campaigns, private militia and groups often disrupted opposition rallies and the ruling party KANU adopted a number of strategies that undermined free and fair elections such as lopsided voter registration, biased electoral commission, intimidation of journalists and banning of print media. For instance, in early 1997, Susan Mosoke, a photographer, was assaulted by the police when covering a story on the deliberate delay in the issuance of identity cards to disenfranchise voters (Auerbach, 2003). The foregoing discussion reveals that during Moi's reign minimal reforms were formulated while the level of human rights violations increased in severity.

\subsection{Theoretical Framework}

The study was guided by the protest theory. The protest theory is a combination of sub theories founded by Dembour in 2011. The theory recognizes human rights as issues that must be raised when they are not socially recognized, and should concern every human being, especially those who are forgotten (Dembour, 2011). The protest theory further maintains that human rights have their origin in struggles, and they will always remain in a continual fight, because of the challenging messages and demands. The theory is called protest because the proponents are not satisfied with the established legal and political discourse on human rights. The idea of human rights as a radical vision for the people can become positive if laws that ensure human freedoms are safeguarded. The protest theory pays attention to the factors that serve as impetus for change. The theory is relevant to the study as it empathizes on maintaining of a pluralist democratic dispensation that allows people to organize and feel committed to collective identities, cultures and traditions that promote change. In this context police reforms are viewed as representing diverse hopes among those who suffer police brutality.

\subsection{Methodology}

The study was guided by the descriptive design. The design provided the researcher with information about the respondents' beliefs and opinions about police reforms and their implication on human rights. The study was based in Nairobi City County. Nairobi City County is a metropolitan county and capital of Kenya. It is highly populated with about half of the residents living in slum areas. The residents constitute a large population coming from diverse geographical, cultural, political and socio-economic backgrounds. The rationale for conducting this study in Nairobi City County was informed by increased cases of violation of human rights in spite of the existing and ongoing police reforms. It was also informed by the fact that agitations for police reforms have been waged in Nairobi since it is the capital town. The target population comprised of senior serving and retired police officers, county government administrators, members of community policing, scholars, political leaders and human rights groups from Nairobi City County. Purposive sampling technique was used to identify the study informants. The informants were selected based on their knowledge on police reforms and human rights since independence. Criteria for inclusion in the study included participants' willingness to take part in the study and familiarity with police reforms and human rights debate in Kenya. The researcher sampled a total of 116 informants. Document analysis, interview schedules and focused group discussions were employed in data collection. The key documents analyzed included government records such as ongoing records of the commission for human rights, government annual reports on police reforms, policy manuals, strategic plans for police service, syllabi for police training, journals and newspapers. Interviews were carried out to gather the respondents' views on police reforms. Qualitative data analysis techniques were adopted. The interviews were tape recorded then transcribed for ease of analysis. The data was categorized based on the research questions. Verbatim expressions obtained from the respondents were retained in order to report precisely what they said. The ethical concerns in this study included confidentiality, anonymity, informed consent and respect for all study participants.

\subsection{RESULTS AND DISCUSSION}

\subsection{Centralization of Power and control of security apparatus}

President Moi centralized all the powers in order to gain full control of all the arms of the government. The police force was used to maintain state powers and to intimidate detractors, opponents and critics. Moreover, through the repeal of several sections of the constitution such as the Public Order Act the police acquired enormous power to curtail freedom of speech, association and assembly. This led to an increase in arrest without 
warrant, detention without trial, torture and assassinations (Throup, 1993). A key informant interview with a retired government administrator in charge of state security before Moi became president revealed that Moi established strong support networks within the police ranks. This enabled him to develop a wide base of knowledge that he later manipulated for his personal gain. According to Nyarota (2001) political manipulation subverted the rule of law and undermined professionalism in the police service, deterring the best recruits and reducing police capacity to protect human rights. Nyarota (2001) also concurs that police often harassed and disrupted human rights activities not only in Kenya but also in many countries in Africa such as Tanzania where the riot police often bundled women and children into vehicles during riots.

\subsection{Crackdown on Mwakenya}

Moi also constantly threatened to use police force against those who engaged in negative and divisive practices (Osse, 2012). In addition to enhancing the capability of the police, Moi increased the fidelity of the police by purchasing their loyalty (Widner, 1992). This was evident during crackdown on Mwakenya. Alleged affiliation to Mwakenya provided the pretext for numerous arrests and detentions. Members of Mwakenya Movement were arrested on the grounds that they were part of the illegal movement, which sought to overthrow Moi's government. This set off a trigger that saw hundreds tried and tortured in the 1980s. During the crackdown everyone in the civil society was targeted particularly university lecturers and student leaders. The police responded to Mwakenya with a heavy hand, where spies would raid the University of Nairobi library and confiscate any books on Marxism, Leninism, and socialism. Purported culprits were given prepared statements and forced to sign. Those who refused were tortured and detained, while those who signed under duress were incarcerated (Nyarota, 2001). These were instances of gross violation of human rights by the police as harassment continued even after the victims were released from prison. In particular, the right to obtain a passport for travelling abroad and government employment was greatly restricted by Kenyan authorities (Widner, 1992). Moreover, torture and inhuman treatment took place most commonly in the period between arrest and detention.

\subsection{The Nyayo Philosophy 1979-1982}

Moi pledged to follow the footsteps of Mzee Jomo Kenyatta. This led to the birth of the Nyayo slogan. Based on the three pillars of love, peace and unity, the slogan was expected to unite Kenyans and promote national development (Widner, 1992). In a focus group discussion with scholars in political science at the University of Nairobi, it was revealed that Moi adopted the Nyayo slogan to control the state, consolidate more powers and legitimize his leadership, purely for political gain. The intended peace, love and unity were not achieved but turned out to be a political ploy and an instrument of political subjugation (Bayley, 1991). Amutabi (2009) concurs that Moi literally followed the authoritarian leadership of Kenyatta which was characterized by corruption, tribalism and human rights abuse. Nyayoism remained in paper. Instead, Moi institutionalized an authoritarian regime with a habit of human rights violations. The introduction of multipartism created a stalemate between Moi and human rights advocates. Despite the reinstatement of multiparty elections and attempts to annul laws that allowed abuse of human rights, government security agents continued to violate civil and individual liberties. As was the case during the de jure one party state rule, human rights violations continued even in post-multiparty elections. Although publicly acknowledging peace, love and unity, Moi persistently demonstrated unwillingness to uphold the sanctity of human rights with frequent ambivalent dealing with violence, rarely fulfilling its obligation to the citizens as enshrined in the constitution and international human rights treaties.

\subsection{The 1982 Attempted Coup}

In 1982 a section of the Embakasi Air Force attempted a military coup that was aimed at overthrowing Moi regime. In a key informant interview with a politician detained after the 1982 coup revealed that the president used all the means available to successfully counter the coup as the coup was met with the highest level of violation of human rights. For instance, those who were found without national identity cards were put in a truck and taken to the Tsavo where they were killed. According to Gimode (2007) the 1982 attempted military coup was marked by rape, innocent killings, torture of innocent individuals and arrests without detention. This was the peak of gross violation of human rights during Moi's leadership. Within the three days that the attempted coup lasted many women were sexually harassed before being killed (retired senior police, KII, 2017). This has been supported by Mutinga (2012) who noted that during the coup over 100 soldiers and 200 civilians lost their lives, including two (West) Germans, an Englishwoman, and a Japanese male tourist and his child. In addition, two Asian women committed suicide after being raped. Hospitals reported that more than 50 people, mainly civilians, had been treated for gunshot wounds. Moi also imposed an indefinite dusk to dawn curfew. In the ensuing confusion, civilians looted stores throughout Nairobi and some looters smashed windows of automobile showrooms and stole cars. According to Widner (1992) the rebels accused the government of imposing a one- 
party state, censuring the press, violating human rights and repression reminiscent of the colonial days.

\subsection{Consolidation of the Powers of the Presidency; 1982-1991}

Following the attempted coup of 1982, Moi instituted a series of reforms that saw him consolidate more powers and took control of all the other arms of the government. The police became an instrument of oppression, intimidation and harassment (Adar \& Munyae, 2001). A constitutional lawyer in Nairobi noted that in 1986, several laws were passed to limit the freedom of the judiciary and the security tenure of the attorney general, state house controller and auditor general, high court judges and the Court of Appeal Judges (Constitutional lawyer, KII, 2017). With such powers accorded to the presidency, Moi stamped his authority over the police. Samora (2014) noted that police officers were recruited mainly from loyal ethnic groups.

In an interview with a senior serving county commissioner who also worked in the provincial administration during Moi regime, revealed that the police detained KANU critics for 14 days while forcing them into submission (County Commissioner, KII, 2017). Generally, detention without trial was the norm with the plain clothed cops listening to and acting on whispers in the wind. The infamous torture chambers at Nyayo House became a nightmare to those who found themselves there. According to Osse (2012) misuse of the police is often seen in the selective denial of human rights and association to political opponents and government critics. Peaceful demonstrations were routinely denied permission to march or assemble in almost all African countries (Osse, 2012). However, international human rights standards allow restrictions on the rights of peaceful assembly and freedom of association only within the law and when necessary in a democratic society in the interests of national security (Nyarota, 2001).

\subsection{Multiparty Politics and the Role of the Police Force, 1992-2002}

According to Kivoi and Mbae (2013) major police reforms in Kenya were the by-products of agitation of multiparty politics. However, none of the strategic reform agendas have altered the fundamental principles of policing. The noteworthy transformations in policing resulting from agitation for political pluralism between 1992 and 2002 included increasing the number of police officers in the police force. When reforms began, many Kenyans regarded the police as ineffective and lost trust in the police. The motive for reform was informed by the need to restore confidence in the police service and to enhance public cooperation in order to guarantee safety and security of everyone (Widner, 1992). However, deaths in the hands of the police were disturbingly common during this period not only in Kenya but across Africa.

According to Osse (2012) human rights organizations expressed concern over the high number of deaths in police custody in Mauritius, Mozambique, South Africa and Zambia. To avoid being implicated the police claimed that the detainee committed suicide or died as a result of illness while in custody. Inquiries and mandatory investigations showed that the majority of these deaths resulted from the use of brutal force by police. In Kenya, the incarceration of agitators of democracy amid public outcry and international condemnation provided one of the most sensational political trials in Kenya in the early 1990s. It attracted huge international attention and put more pressure on Moi to allow multi-party democracy. Moi ultimately gave in to pressure and in December 1991, allowed Parliament to repeal Section 2 (A) of the Constitution to allow multiparty democracy. The new political dispensation was a nightmare for Kanu as it attracted scores of dissatisfied politicians and academicians to form FORD (a political party) as the outfit to remove Kanu from power and consign years of political dictatorship to the dustbin of history (Adar, 1999). A retired senior provincial administrator who worked during Moi regime noted that the violence was often politically instigated and the GSU were often used as an instrument of violence against organized multiparty activities (retired senior provincial administrator, KII, 2017). In addition, a victim of the 1992 ethnic violence in Nairobi noted that the police witnessed the raids by armed militias but did nothing to stop it (Victim of Violence, O.I, 2017). The police watched while the civilians were assaulted yet the national legislation governing police operations requires police officers to discharge their duties in apolitically non-partisan manner, showing no bias or favouritism towards any political party or ethnic group. The police are required to act with neutrality and impartiality, not to discriminate against someone because of their political affiliation and not to show support for any political party (Adar \& Munyae, 2001). However, the reality is that the police in many African countries have been used for political ends to disperse demonstrations by the opposition and to promote the ruling party. This took place yet the police act does not allow officers to align themselves to any political organization in a public manner but are required to discharge their duties in a non-partisan manner.

\subsection{Conclusion}

From the foregoing discussions, it is evident the period between 1978 and 2002 was marked by heightened human rights violation by the police with little efforts to reform the police. The president exploited his power over the police force and used it to repress political opponents. The legislature and the judiciary were also controlled by the presidency. In addition, the regime revoked some of the laws that limited the power of the 
president. This allowed the president to consolidate and maintain state power including the police. It is in this respect that the regime was marked by police brutality against the citizens. In the absence of police reforms in this era, there were rampart arrests without warrants, detention without trial and torture. Excessive use of force in the course of arrest often resulted in injury and death. This implied that the police did not apply the necessary restraints in the course of carrying out their duties. Hence, the period was marked by curtailed freedom of association, assembly, speech and expression. The citizens, media and the different faith groups lost their voice. Enormous violation of human rights was witnessed during elections where the police unleashed violence and fanned ethnic hatred. This nonpartisan policing occurred even though constitutional repeal in 1997 criminalized the use of excessive force on the common citizens. Hence, the period between 1978 and 2002 marked heightened human rights violation without corresponding efforts to reform the police.

\subsection{REFERENCES}

Adar, K. G. (1999). Human rights and academic freedom in Kenya's public universities: the case of the university's academic staff union. Human Rights Quarterly, 21(1), 179-206.

Adar, K. G., \& Munyae, I. M. (2001). Human Rights Abuse in Kenya under Daniel Arap Moi, African Studies Quarterly, 5(1).

Ajulu, R. (2002). Politicized ethnicity, competitive politics and conflict in Kenya: a historical perspective. African Studies, 61(2), 251-268.

Amutabi, M. (2002). Crisis and student protest in universities in Kenya: Examining the role of students in national leadership and the democratization process. African Studies Review, 45(2), 157-177.

Auerbach, N. (2003). Police Accountability in Kenya: Seize the Moment, Commonwealth Human rights Initiative. New Delhi.

Bayley, D. H. (1991).Forces of Order: Policing Modern Japan. Berkeley, CA: University of California Press.

Bruce, D. (2006). Democratic Reform of Police-Any Lessons for Kenya from South Africa? Johannesburg, South Africa: Center for the Study of Violence and Reconciliation.

Dembour, M. (2011). What are human rights? Four Schools of thought, Human rights Quarterly, V1. 32, 1-20

Garland, D. (1996). The Limits of the Sovereign State: Strategies of Crime Control in Contemporary Society. British Journal of Criminology, 3(6) 445-471.

Gimode, E. (2007). The Role of the Police in Kenya's Democratization Process. London: Zed Books.

Hahn, H. D. (2003). Urban American and its Police: From the Post-Colonial Era through the turbulent 1960s. Boulder, USA: University Press of Colorado.

Hannan, L. (1991). Bias and Judicial Outrage. New Law Journal 141: 900-901

Haugerud, A. (1995). The Culture of Politics in Modern Kenya, Cambridge: Cambridge University Press.

Kivoi, L. K. \& Mbae, C. G. (2013). The Achilles' Heels of Police Reforms in Kenya. Social Sciences, 2(6)189-194.

Maina, W. (1996). Constitutional Crisis in Kenya: An Inquiry into the Origins, Nature and Prospects of Reform, Paper Presented to the IPAR Project on Constitution-Making in Kenya.

Moi, D. T. (1986). Kenya African Nationalism: Nyayo Philosophy and Principles. London: Macmillan.

Mutinga, K (2012). Moment of bravado that changed Kenya. Daily nation. Available at http: //www.nation.co.ke/lifestyle/dn2/How-1982-coup-changed-Kenya/957860-46748813vl42az/index.html

Mutua, M. (1993). A long Road to Uhuru: Human Rights and Political Participation in Kenya. Montreal: International Centre for Human Rights and Democratic development.

Nyarota, G. (2001). Policing to protect human rights: A survey of police practice in countries of the Southern African Development Community, 1997-2002, London: Amnesty International.

Osse, A. (2012). Understanding Policy: A resource for human rights activists, Geneva: Amnesty International

Ross, S. (1992). The Rule of Law and Lawyers in Kenya, Journal of Modern African Studies, 30(3): 428

Sabar-Friedman, G. (1997). Church and State in Kenya, 1986-1992: The Churches' Involvement in the Game of Change, African Affairs, 96: 25-52.

Samora, M. (2014).10 things the 1982 coup changed. The standard digital available at: https://www.standardmedia.co.ke/ article/2000130190/10-things-the-1982-coup-changed

Savage, S. P. (2007). Police reform: Forces for Change. USA: Oxford University Press.

Skogan, W. G. (1993). Why reforms fail. Policing and Society: An International Journal of Research and Policy, 18(1), 23-34.

Throup, D. (1993). Elections and political legitimacy in Kenya, Africa, 63(3), 371-396.

Waller, R. (2012). Toward a History of Violence in Colonial Kenya, the International Journal of African Historical Studies, 45(1), 1-7

Widner, J. (1994). Two Leadership styles and Patterns of Political Liberalization, African Studies Review, 37(1):151-174.

Widner, J. A. (1992). The Rise of a Party-State in Kenya: From "Harambee!" to "Nyayo!" Berkeley: University of California. 